\title{
Article \\ Efficiency of Harvester with the Debarking Head at Logging in Spruce Stands Affected by Bark Beetle Outbreak
}

\author{
Václav Merg1 ${ }^{1, * \mathbb{C}}$, Tomáš Zemánek ${ }^{1}{ }^{\mathbb{D}}$, Marian Šušnjar ${ }^{2}$ and Jan Klepárník ${ }^{1}$ \\ 1 Department of Engineering, Faculty of Forestry and Wood Technology, Mendel University in Brno, \\ 61300 Brno, Czech Republic; tomas.zemanek@mendelu.cz (T.Z.); jan.kleparnik@mendelu.cz (J.K.) \\ 2 Department of Forest Engineering, Faculty of Forestry and Wood Technology, University of Zagreb, \\ 10000 Zagreb, Croatia; msusnjar@sumfak.hr \\ * Correspondence: xmerg11@mendelu.cz; Tel.: +420-545-134-305
}

\section{check for}

updates

Citation: Mergl, V.; Zemánek, T.; Šušnjar, M.; Klepárník, J. Efficiency of Harvester with the Debarking Head at Logging in Spruce Stands Affected by Bark Beetle Outbreak. Forests 2021, 12, 1348. https://doi.org/ 10.3390/f12101348

Received: 20 August 2021

Accepted: 27 September 2021

Published: 2 October 2021

Publisher's Note: MDPI stays neutral with regard to jurisdictional claims in published maps and institutional affiliations.

Copyright: (c) 2021 by the authors. Licensee MDPI, Basel, Switzerland. This article is an open access article distributed under the terms and conditions of the Creative Commons Attribution (CC BY) license (https:// creativecommons.org/licenses/by/ $4.0 /)$.

\begin{abstract}
This paper deals with the use of debarking modifications of the conventional harvester head in the conditions of felling due to bark beetle calamity. For this purpose, a time study was established, in which the conventional heads were compared with the heads with debarking modifications on four research plots and two harvesters. The measurements were taken from August to September 2018. Harvester efficiency with the use of the head with the debarking configuration ranged from $41.2 \%$ to $41.8 \%$ from the efficiency of a machine with the conventional head, depending on the felling type. It was also demonstrated that the quality of debarking does not depend on the trunk moisture content in the growing season. In terms of diameter, it was found that the best debarked parts of the stem were those occurring in its middle. Specifically, in the central part of the stem with a diameter of 13 to $23 \mathrm{~cm}, 91.0 \%$ of the stem area was debarked in the main felling and $76.6 \%$ in the thinning. In contrast, the top parts of the stem (trunk diameter up to $13 \mathrm{~cm}$ ) were the least debarked. In the main felling, it was $74.2 \%$ of the stem area and in the thinning, only $52.2 \%$.
\end{abstract}

Keywords: harvester; efficiency; harvesting head; debarking; Norway spruce; damaged logs; bark beetle

\section{Introduction}

Central Europe currently faces a bark beetle calamity. Between 2017 and 2019, 270 million $\mathrm{m}^{3}$ of timber was harvested in this part of Europe due to windstorms and bark beetles [1]. The most affected countries are Germany, the Czech Republic, and Austria [2].

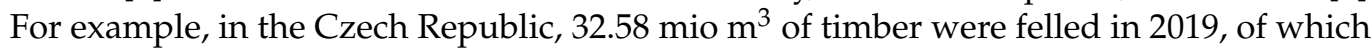
the share of incidental felling was 95\% [3]. In 2016, the share of incidental felling in the Czech Republic before the bark beetle calamity was 53\% from a total amount of 17.61 mio $\mathrm{m}^{3}$ of felled timber [4]. Most widely attacked by the insects was Norway spruce (Picea abies L.), which is popular in Europe for economic reasons [5]. In the past, economic reasons led to its growing in monocultures [6]. However, with the global climate change, these monocultures are exposed to drought and high temperatures $[7,8]$, which increase the stress burden on these stands and reduce their resilience to insect pests [9]. This is why further bark beetle calamities can be expected in the near future [10,11]. Currently, up to 27.4 billion $\mathrm{m}^{3}$ of spruce forests in Europe are potentially endangered [12].

The facts indicate that a method should be quickly found for the sanitation of the infested wood. There are currently many sanitation methods that can be divided into three categories, according to Zahradník et al. [13]. The first of them is a biological category, which makes use of natural predators such as birds or Beauveria bassiana [14,15]. The second category of sanitation methods uses the manual or mechanized application of chemicals onto the surface of the cut stem. An example of the mechanized application of chemical substances can be harvester head modification for spraying the processed stem [16]. The third method is mechanical sanitation, which is implemented either by stem 
debarking or by scraping the bark (removal of bark only in strips parallel to the stem axis). Debarking is conducted in the forest or at the roadside landing with the use of simple hand tools or a power saw with a debarking adapter [17]. Fully mechanized debarkers are mostly used at timber yards. A new opportunity to improve debarking efficiency directly in forests is the possibility of deploying harvesters with the debarking configuration of conventional heads. These types of heads can be used, for example, in localities with increased protection of water sources where the application of chemicals is prohibited [18].

The use of debarking heads has so far been limited only to eucalyptus plantations due to the problematic bark bond strength, which is extremely sensitive to moisture content [19]. Logs are best debarked right after felling and the consumption of energy is lower [20,21]. Today, conventional harvester heads are available on the market with modifications of individual components, which can be purchased and mounted on the already owned head. The reason for the modifications of conventional heads is the increased flexibility in their use and lower purchasing costs compared with the debarking heads developed on eucalyptus [22].

Conventional heads for debarking can be divided into three categories, according to the number of their modified parts. The first category includes only modified feed rollers. Bennemann et al. [23] claim that a representative of this category is the Log Max 7000C model manufactured by Log Max AB. The modification of feed rollers is represented by the replacement of spikes or horizontal roller ribs with spiralized ribs [22,24]. Thanks to this improvement, the stem rotates around its longitudinal axis while being processed, thus helping the debarking knives remove bark more perfectly from the entire stem surface [25]. Furthermore, if these modified feed rollers have an added wider and less aggressive length measuring wheel, we can describe another category whose representative is John Deere with the H480C head [23]. The new measuring wheel has the task of maintaining or enhancing the accuracy of the measurement [22]. The third category of conventional heads intended for debarking features identical modifications such as in categories 1 and 2 as well as an additional modification of upper delimbing knives and fixed lower delimbing blade [25].

In addition to all the above-mentioned technical modifications, it is also necessary to reduce the pressure of feed rollers and delimbing knives, and feed rate as well as to calibrate the length measuring system [23]. For their correct function, the pressure of delimbing knives has to be reduced by $30 \%$ compared to the normal pressure [26]. The work procedure with conventional heads modified for debarking also differs from the standard procedure. When the stem is processed by the head, the tree has to be pulled through several times to achieve the correct debarking quality [18]. Good debarking requires the trunk to be pulled through three times as a minimum with the first two operations for trunk debarking and the third for stem processing [27].

Thanks to this technology, it is possible to predict a lower harvester efficiency, as mentioned by Zahradník et al. [13]. The first studies showed a decrease in efficiency by $48 \%$ [22] or by $1 / 3$ [23], but so far, these statements have not been verified in the thinning. Furthermore, global climate change affects the amount of precipitation in the growing season $[7,28]$, and thus the water content in tree trunks. It can be assumed that changes in the moisture content of the trunks during the growing season affect the quality of debarking. Verification of the above topics is the main goal of this article.

\section{Materials and Methods}

\subsection{Research Plots}

Research plots were selected based on the following criteria. The first criterion was the occurrence of Norway spruce (Picea abies (L.) Karsten). The following condition was that of approximately the same mean tree volume for the species and the identical terrain inclination. In total, four plots were selected on two sites in the Czech Republic. The measurements were taken from August to September 2018. Prior to the measurement, the highest daily temperatures during the entire growing season were recorded. At the 
beginning of August, the daily air temperature was marked as a record high in 5 consecutive cases. Specifically, it ranged from $35.3^{\circ} \mathrm{C}$ to $36.1^{\circ} \mathrm{C}$. The measurements were preceded by 47 days with a daily air temperature of $30^{\circ} \mathrm{C}$, whereas extreme drought in Central Europe took place during the growing season, especially in August and July [29].

The first two plots were situated in central Bohemia (Figure 1) close to the town of Benešov. The plots were subjected to the main planned felling, namely clear cutting. On the first plot in this locality, the mean tree volume under bark (u.b.) was $1.19 \mathrm{~m}^{3}$ (Table 1) and a harvester with the conventional head was deployed. The plot was designated as MF (main felling). The mean tree volume of Norway spruce on the second plot was $0.98 \mathrm{~m}^{3}$ u.b. (Table 1). There, a harvester with the debarking modification of the conventional head was deployed, and this is why the plot was designated as MFD (main felling debarking). The terrain gradient of both plots was $0 \%$. In both plots, the first phase of the bark beetle attack took place in $80 \%$ of the trees.

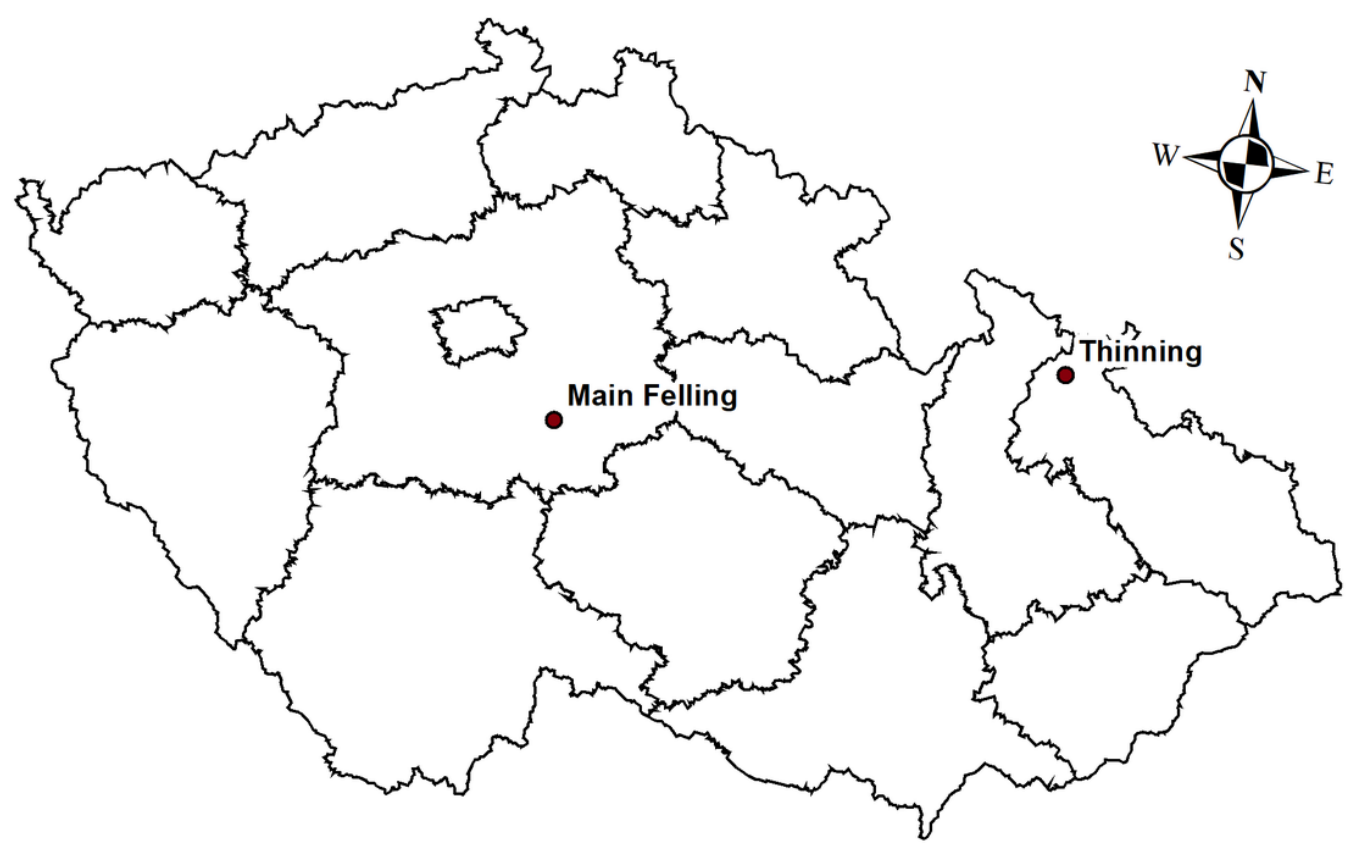

Figure 1. Location of the research plots.

Table 1. Basic information on the research plots.

\begin{tabular}{|c|c|c|c|c|c|c|}
\hline Research Plots & GPS Coordinates & Type of Head & Abbreviation & $\begin{array}{c}\text { Mean Tree } \\
\text { Volume }\left(\mathrm{m}^{3} \text { u.b.) }\right.\end{array}$ & $\begin{array}{c}\text { Terrain } \\
\text { Gradient } \\
(\%)\end{array}$ & $\begin{array}{c}\text { Number of } \\
\text { Processed } \\
\text { Trees }\end{array}$ \\
\hline \multirow{2}{*}{ Main Felling } & \multirow{2}{*}{$\begin{array}{l}49^{\circ} 48^{\prime} 45.366^{\prime \prime} \mathrm{N} \\
14^{\circ} 54^{\prime} 11.205^{\prime \prime} \mathrm{E}\end{array}$} & Conventional & MF & 1.19 & 0 & 170 \\
\hline & & Debarking & MFD & 0.98 & 0 & 100 \\
\hline \multirow{2}{*}{ Thinning } & \multirow{2}{*}{$\begin{array}{l}50^{\circ} 8^{\prime} 23.214^{\prime \prime} \mathrm{N}, \\
17^{\circ} 24^{\prime} 17.370^{\prime \prime} \mathrm{E}\end{array}$} & Conventional & $\mathrm{T}$ & 0.66 & 14 & 190 \\
\hline & & Debarking & TD & 0.60 & 14 & 110 \\
\hline
\end{tabular}

The other two plots on which improvement felling measures in over 40 years of stand age were carried out were situated in northern Moravia (Figure 1), near the town of Albrechtice. In the first plot, the mean tree volume was $0.60 \mathrm{~m}^{3} \mathrm{u}$.b. (Table 1). This stand was designated as TD (thinning debarking) because a harvester with the debarking modification of the conventional head was used to implement the measure. The mean Norway spruce tree volume on the other plot where a harvester with the conventional head was used was $0.66 \mathrm{~m}^{3}$ u.b. (Table 1). This is why the plot was designated as T (thinning) 
for the purposes of this study. The terrain gradient of the two plots was $14 \%$. In both areas, the first phase of the bark beetle attack took place in $50 \%$ of the trees.

\subsection{Harvesters}

The harvesters were operated by two persons, one in the main felling at the first location, and the other in the improvement felling at the second location. Both operators used the same technological procedure at work. In the main felling, the operator worked with the harvester Ponsse Ergo 8 W. In the improvement felling over 40 years, the operator worked with the Ponsse Scorpion King harvester. Both of these machines (Figure 2) were equipped with the harvester head H7 made by Ponsse Plc. (Vieremä, Finland), which also manufactured the harvesters. Each head was further equipped with a debarking set with delimbing knives modified for barking, feed rollers with ribs in a spiral, and a wider length measuring wheel. Thus, the harvester head fell in the third category and its modifications are shown in Figure 2A-C.
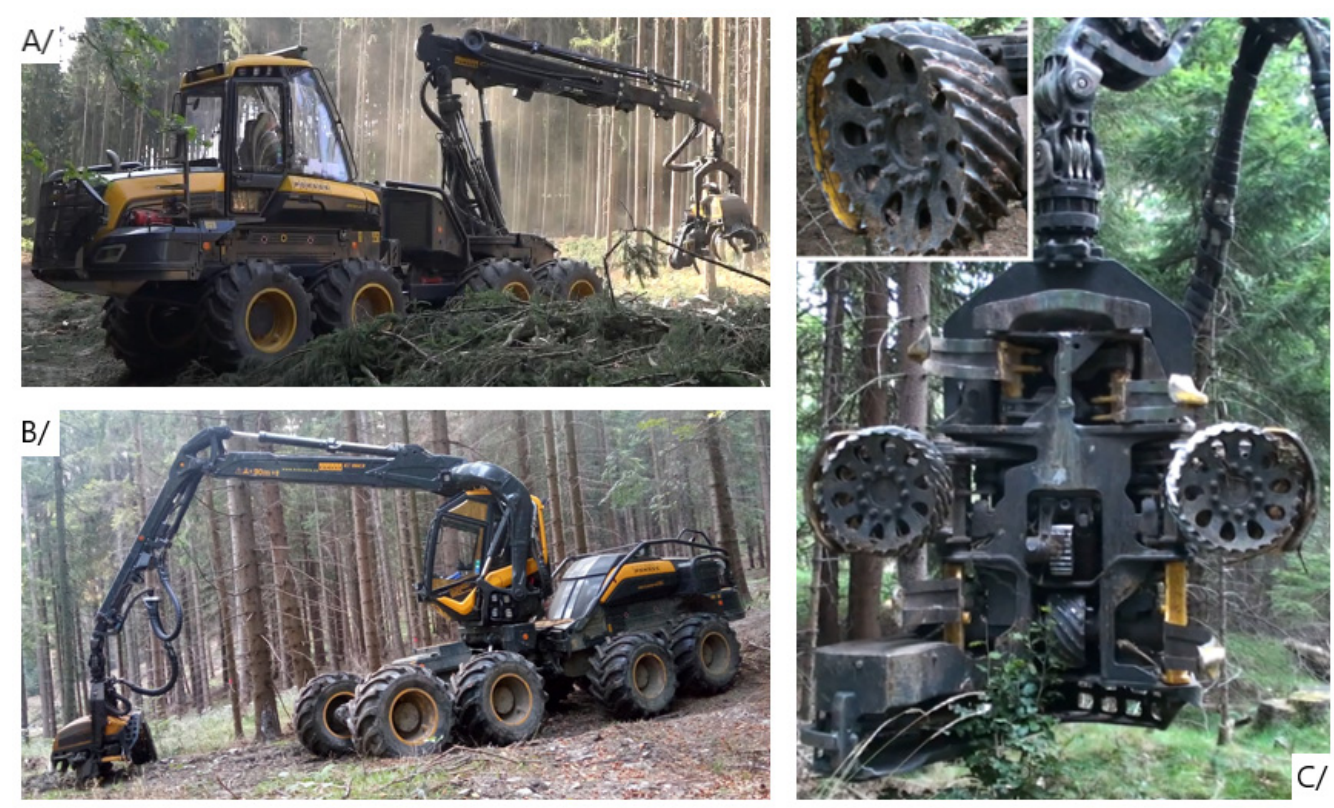

Figure 2. (A) Ponsse Ergo 8 W harvester; (B) Ponsse Scorpion King harvester; (C) Modifications of the H7 harvester head.

After the modification of the harvester head, the technology of stem processing is different to the standard procedure $[18,19]$. The cut tree is pulled through the harvester head for delimbing and the first debarking throughout its full length without cross-cutting. Then, it is released from the head and once again gripped by the harvester head at the small end so that the upper delimbing knives are turned toward the stem base and the second debarking is carried out. Then, a change in harvester head position on the stem base follows, and the third debarking is made along with the cross-cutting. The lengths of the logs were 2,3 , and $4 \mathrm{~m}$.

\subsection{Time Study}

The work of harvesters was evaluated using the method of time study. A camera recording was made at HD resolution. A total length of the record was $120 \mathrm{~min}$ for each research plot. The obtained recording of the manufacturing process was then analyzed by the respective work operations:

- Searching-Time section from the first movement of hydraulic crane toward a tree chosen for felling up to the head attachment onto the trunk and subsequent start of the cutting mechanism. 
- Felling-Time that elapsed from the start of the cutting mechanism to the return of cutting bar back to the initial position.

- Tree fall-Time section from the return of the cutting mechanism back to the initial position to the fall of tree crown onto the ground.

- Handling-Time required to place the trunk in a position suitable for further processing. Time from the crown tree fall to the start of the feeding mechanism.

- Delimbing-Time section during which the tree trunk in the harvester head is in motion thanks to the feeding mechanism. This time section is always interrupted by stopping the stem for cross-cutting, and started again when the stem begins to move. The cycle is repeated until the last stop of the stem in the head. For the debarking head, this work operation can be divided as follows:

○ Phase 1-From the start of the feeding mechanism on the stem base to the release of the trunk small end from the head and trunk falling onto the ground. Time when the trunk shifting stopped due to its placement into a more favorable work position by the hydraulic crane was included into the operation of handling.

- Grip change 1-From the moment when the trunk hits the ground to the repeated gripping of the trunk small end by the turned head.

- Phase 2-From the start of the feeding mechanism on the trunk small end to the release of the trunk base from the head and trunk falling onto the ground. Similarly, as in Phase 1, the same rule applies to the head stop.

- Grip change 2-Time section from the trunk falling onto the ground to the trunk base being caught in the head and cutting mechanism aligned with the butt end of the trunk (and its start). The following alignment cut was included into the operation of handling.

- Phase 3-This operation was measured in the same manner as delimbing in the conventional harvester head.

- Cross-cutting-Time section in the course of delimbing when the trunk stops moving in the head and is handled by the hydraulic crane to the place where the particular assortment is going to be stored, which is produced by the subsequent cross cutting also included in this part. The operation ends with the repeated start of the feeding mechanism of the head. The cross-cutting is terminated when the last assortment is placed and the stem top part is released.

- Machine movement-Time section in the course of which the machine was moving after the end of cross-cutting to a new position where searching was to be started.

Trunks meant for debarking were subjected to the recording of current moisture content and debarking quality.

\subsection{Moisture Content}

The moisture content was measured by using the WHT 860 tip wood hygrometer (Elbez s.r.o., Velké Meziříčí, Czech Republic). The measurement accuracy was 0.2\%. Measuring points were set out at a repeated distance of 1.5 from each other, beginning from the butt end of the stem. Thus, in each defined point, five values of moisture content were measured on the stem perimeter, which were recorded in the field book for the respective assortment. It is important to mention that the distance was given by the length of produced assortments $(2,3$, and $4 \mathrm{~m})$ and by the condition that the point of measurement must not be situated less than $50 \mathrm{~cm}$ from the log edge. The location of the moisture measuring points on the trunk is shown in Figure 3. A total of 424 logs were measured. 


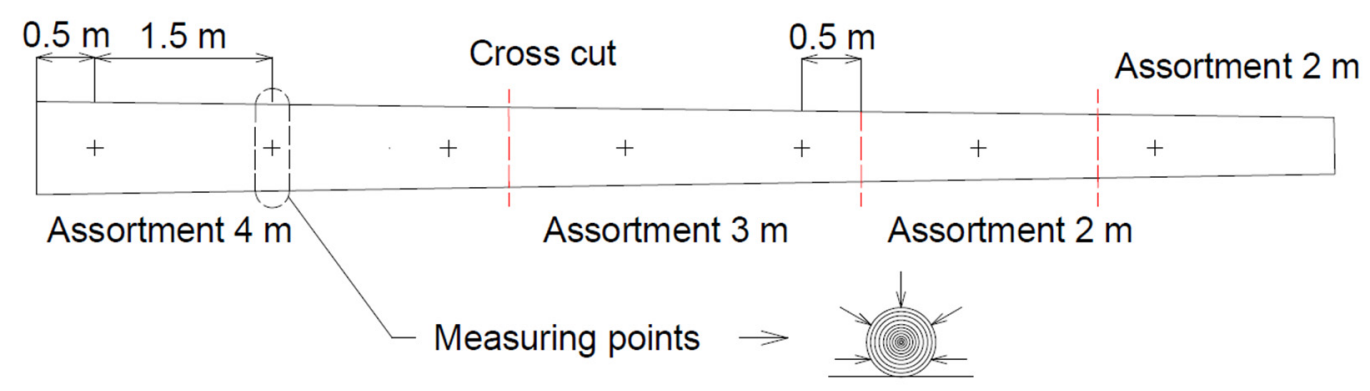

Figure 3. Location of moisture measuring points on the trunk.

\subsection{Debarking Quality}

The quality of debarking was evaluated by the ocular estimate of one person for three diameter sections in the main felling (up to $13 \mathrm{~cm}, 13-23 \mathrm{~cm}$ inclusive, and over $23 \mathrm{~cm}$ ) and for two diameter sections in the improvement felling (up to $13 \mathrm{~cm}$ and over $13 \mathrm{~cm}$ inclusive). Logs were classified in the sections according to the value of small end diameter detected by the calibrated caliper. Debarking quality was determined as a percentage of the share of log surface under bark on a scale divided by five percentage points. Prior to the evaluation, the person tried to estimate the quality of debarking on six logs in which the percentage of debarked surface was ascertained by a 3D scanner. For the measurement, we used static panoramic scanner "Phase-shift" Faro Focus 3D (Faro, Lake Mary, Florida, US). Prior to proper measurement, we had to set resolution, quality, and spatial range. From one measuring position, one image was made at a resolution of $1 / 4$. Scanning quality was adjusted to the mean value $4 \times$, which guarantees sufficient quality of measurement at relatively fast scanning. Spatial range was set to $0-180^{\circ}$ in horizontal direction and to $-60-90^{\circ}$ in the vertical direction. Before the measurement was started, black-and-white targets were placed on the measuring face, which served to connect all scanned positions in the subsequent processing. All logs were scanned from four sides. The share of the bark was then determined on a digital model of the log.

The produced logs were also inspected for damage to their surface by feed rollers or delimbing knives. Damaged logs were those whose shape was altered by more than $30 \%$ compared with the initial shape before processing or when wood fibers were torn from them. After the assortment had been allocated to the stem, mean damage was calculated for the whole stem. If the share of damaged assortments exceeded $30 \%$ from the total amount of assortments produced from one stem, the stem was considered as damaged.

\subsection{Statistical Analyses}

The field records were entered as SI system timecodes in the following format: hh:minmin:ss. The records modified in this manner were then added as data on the duration of the respective work operations and undesirable extremes (non-standard work operations in the record) were removed. A box plot was used for this purpose. Then, the Shapiro-Wilk test of data normality was used with a $p$-value of 0.05 .

In one locality (main felling or improvement felling), two plots were compared on which the felling was made with and without barking. A $t$-test was used in the case of data normality, and the Mann-Whitney test was used if the data had not been divided normally. Both tests were performed at a significance level of 0.05 .

Data obtained from the measurement of moisture content in heads with the debarking modification in the defined points on the individual assortments were processed similarly at the beginning as the previous data (i.e., using a box plot to remove undesirable extremes in each measuring point). Data from debarking were processed similarly to those of moisture content, but without a box plot because the log was evaluated by only one value. Then, a multiple regression was performed with a $p$-value of 0.05 to find out whether the quality of debarking depends on the stem moisture content. After the statistical analysis, the individual assortments and data (moisture content and quality of barking) were allocated 
to the stem from which they were produced. The classification of assortments was followed by the calculation of mean value for the given stem.

After this analysis, the processed data on the quality of debarking in the individual stem sections were subjected to the Shapiro-Wilk test of normality with the same $p$ level of significance as in data from the time study. Further tests were one-way ANOVA in the case of data normality, and the Kruskal-Wallis test in the opposite case. These tests were used only in the case where the machine worked in the main felling as there were three sections to compare. In the improvement felling, only tests for the comparison of two samples were used as the third section was not recorded there. If the data were normally divided, a $t$-test was used. A Mann-Whitney test was used in the opposite case. All these tests were performed at the same $p$-value of 0.05 . The two last tests with the same $p$-value were used in the further phase of data processing, which included a comparison of the same sections between the MFD plots, etc.

\section{Results}

The results of the time study were based on a camera recording of $120 \mathrm{~min}$. The tree fall parameter exhibited differences only on the plots with the main felling. On average, the tree was falling faster on the MF plot, but only by $0.1 \mathrm{~s}$. The reason for the trees falling faster than on the MFD plot was a lower concentration of the crowns of trees standing in the tree fall line.

On the other hand, the statistical analyses demonstrated differences of data in the two localities in the parameter of delimbing. Stems were at all times delimbed faster with the use of the conventional harvester head without the debarking modification. The machine operator in the main felling could delimb the stem using the head with the debarking set on average within $36.3 \mathrm{~s}$, which was $28.4 \mathrm{~s}$ more than with the use of the conventional head. Responsibility for this high time consumption fell to Phase 1 (19.2\%), Phase $2(16.8 \%)$, and Phase $3(22.1 \%)$. The rest can be accounted for by Grip change $1(19.9 \%)$ and Grip change $2(22.0 \%)$. The results were similar compared with the improvement felling plots. In the improvement felling with the harvester head equipped with the debarking set, a trunk was delimbed on average within $32.0 \mathrm{~s}$, which was by $26.3 \mathrm{~s}$ slower than with the conventional head. Time consumption for trunk processing was $18.1 \%$ (Phase 1), $16.9 \%$ (Phase 2), and $21.6 \%$ (Phase 3). Grip change 1 consumed $20.9 \%$ and Grip change 2 consumed $22.5 \%$ of time. A work operation with statistically significant differences was found only in the improvement felling was cross-cutting. A difference between them was on average $1.1 \mathrm{~s}$ in favor of $\mathrm{T}$, which resulted from the lower concentration of movement before the cross-cutting within the work technology. More values from the time study are presented in Table 2. Results of statistical analyses are shown in Table 3. Regarding the working operations searching, felling, handling and machine movement, no statistically significant differences were found between the compared plots.

Table 2. Results of the time study.

\begin{tabular}{|c|c|c|c|c|c|c|c|c|c|c|c|c|c|c|c|c|}
\hline \multirow[t]{2}{*}{$\begin{array}{l}\text { Research } \\
\text { Plots }\end{array}$} & \multicolumn{2}{|c|}{$\begin{array}{l}\text { Searching } \\
\text { (s) }\end{array}$} & \multicolumn{2}{|c|}{ Felling (s) } & \multicolumn{2}{|c|}{ Tree Fall (s) } & \multicolumn{2}{|c|}{$\begin{array}{l}\text { Handling } \\
\text { (s) }\end{array}$} & \multicolumn{2}{|c|}{$\begin{array}{l}\text { Delimbing } \\
\text { (s) }\end{array}$} & \multicolumn{2}{|c|}{$\begin{array}{l}\text { Cross } \\
\text { Cutting } \\
\text { (s) }\end{array}$} & \multicolumn{2}{|c|}{$\begin{array}{c}\text { Machine } \\
\text { Travel } \\
\text { (s) }\end{array}$} & \multicolumn{2}{|c|}{$\begin{array}{l}\text { Total Time } \\
\text { per Tree (s) }\end{array}$} \\
\hline & $\mu$ & $\sigma$ & $\mu$ & $\sigma$ & $\mu$ & $\sigma$ & $\mu$ & $\sigma$ & $\mu$ & $\sigma$ & $\mu$ & $\sigma$ & $\mu$ & $\sigma$ & $\mu$ & $\sigma$ \\
\hline MF & 5.0 & 1.2 & 2.2 & 0.3 & 5.7 & 1.1 & 4.0 & 2.1 & 7.9 & 1.1 & 11.1 & 1.9 & 6.1 & 1.5 & 42.0 & 4.5 \\
\hline MFD & 5.1 & 1.1 & 2.2 & 0.3 & 5.8 & 0.7 & 4.4 & 2.5 & 36.6 & 4.2 & 11.7 & 1.6 & 6.0 & 1.2 & 71.4 & 5.9 \\
\hline $\mathrm{T}$ & 4.9 & 1.1 & 1.1 & 0.2 & 6.2 & 2.2 & 1.6 & 1.3 & 5.7 & 0.8 & 12.6 & 1.8 & 5.7 & 1.1 & 37.7 & 3.7 \\
\hline TD & 5.7 & 2.0 & 1.2 & 0.3 & 6.8 & 3.2 & 2.7 & 2.4 & 32.0 & 4.2 & 10.9 & 2.2 & 5.6 & 1.4 & 64.8 & 8.4 \\
\hline
\end{tabular}


Table 3. Results of the statistical analysis of the time study.

\begin{tabular}{ccccccccc}
\hline & \multicolumn{9}{c}{ Operations } \\
\cline { 2 - 8 } Research Plots & Searching & Felling & Tree Fall & Handling & Delimbing & $\begin{array}{c}\text { Cross } \\
\text { Cutting }\end{array}$ & $\begin{array}{c}\text { Machine } \\
\text { Travel }\end{array}$ & $\begin{array}{c}\text { Total Time } \\
\text { per Tree }\end{array}$ \\
\cline { 2 - 8 } & $p$-Value & $p$-Value & $p$-Value & $p$-Value & $p$-Value & $p$-Value & $p$-Value & $p$-Value \\
\hline MF vs. MFD & $>0.10$ & 0.78001 & 0.03416 & 0.637695 & 0.000000 & 0.262064 & 0.167021 & 0.000000 \\
T vs. TD & 0.12407 & 0.13524 & 0.52545 & $>0.10$ & 0.000000 & 0.012612 & 0.286232 & 0.000000 \\
\hline
\end{tabular}

Marked number $=$ research plots are different.

In general, a higher time consumption was demonstrated for the processing of one trunk with the use of a harvester head with the debarking set. A trunk in the main felling was processed by the operator using the conventional head, on average, in $42.0 \mathrm{~s}$ (Table 2). In the case of using the debarking set, the time consumption increased to $71.4 \mathrm{~s}$. This indicates that the time difference for the processing of one trunk in the main felling and in the improvement felling was $41.2 \%$ and $41.8 \%$, respectively.

Regarding the quality of stem debarking, it was found that in the main felling, the bark was removed from the stem surface at $84.5 \%$ on average. In the improvement felling, the average was $64.5 \%$. A closer look at the values of debarking in the respective sections revealed a statistically significant difference between the sections in both localities, with an exception of the second and third sections in the main felling (Table 4). The best results of debarking in both localities were achieved in the section from 13 to $23 \mathrm{~cm}$, and the worst results were recorded in the section of up to $13 \mathrm{~cm}$ (Figure 4), which was given by the geometry of delimbing knives and technology of the grip of the harvester head on the stem base. In the main felling, section 1 was debarked on average at $74.2 \%$ (Figure 4 ), which was $16.8 \%$ less than section 2 and $13.7 \%$ less than section 3 . The improvement felling provided similar results. Section 1 was debarked on average at $52.2 \%$ and section 2 at $76.6 \%$. When sections 1 and 2 in the two localities were compared, statistically significant differences were found (section 1: $p$-value 0.000799, section 2: $p$-value $<0.005$ ). Better results of debarking were achieved in the main felling. Section 1 differed by an area surface of $22.0 \%$, and section 2 by an area surface of $14.4 \%$.

Table 4. Statistical results of the comparison of the debarked stem sections.

\begin{tabular}{cccc}
\hline MFD & Diameter Section 1 & Diameter Section 2 & Diameter Section 3 \\
\hline Diameter Section 1 & & 0.000043 & 0.006638 \\
Diameter Section 2 & 0.000043 & & 0.600496 \\
Diameter Section 3 & 0.006638 & 0.600496 & \\
TD & & $p$-value & \\
Diameter Sections 1 vs. 2 & & 0.000371 & \\
\hline
\end{tabular}

Marked value $=$ diameter sections are different.

Damage to trunks at delimbing and debarking was recorded only in the improvement felling where $50 \%$ of produced logs were affected (Figure 5). Thus, the quality of debarking sections 1 and 2 was worse compared with the main felling. Our measurements did not demonstrate any dependence of debarking quality on the trunk moisture content ( $p$-value for the main felling of 0.608194888 and for the improvement felling it was 0.522094905 ). The average trunk moisture content in the main felling was $75.9 \%$ (standard deviation was 6.5), and in the improvement felling, it was $58.0 \%$ (standard deviation was 18.7). 


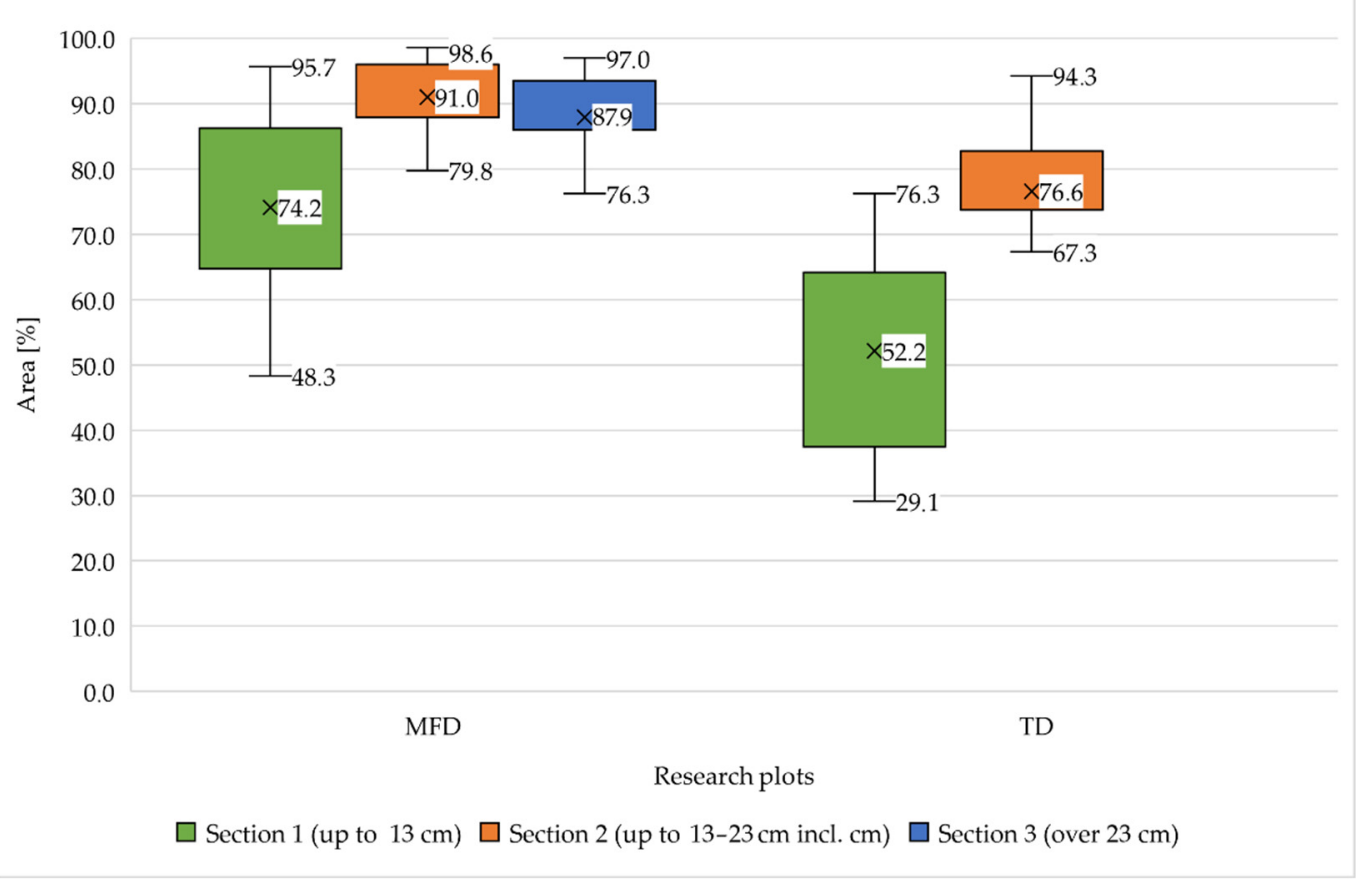

Figure 4. Debarking quality of the logs.

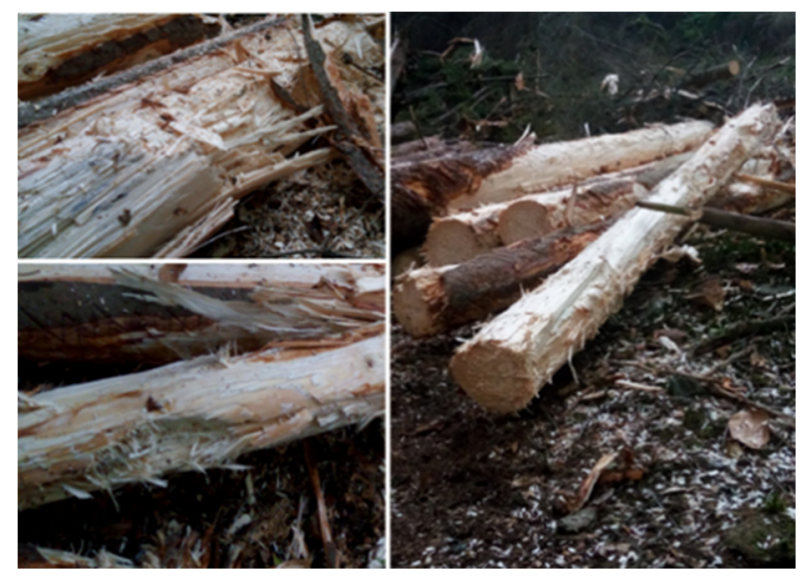

Figure 5. Damage to logs.

\section{Discussion}

It was found that the efficiency of a harvester with the head equipped with the debarking set was $41.2-41.8 \%$ lower (depending on the type of felling) than the efficiency of a harvester with the head without the debarking set. In similar research, Heppelmman et al. [22] recorded a difference in the efficiency by $48 \%$. Bennemann et al. [23] observed the harvester output reduced by a third. This result is in line with the statement that the use of debarking heads reduced the machine efficiency $[13,24]$. The increased time consumption in harvester heads with the debarking set resulted from a different work procedure, namely in the delimbing/debarking work operation, which lasted nearly as long as the total time required for the processing of one trunk in heads with the debarking set. An average difference between delimbing/debarking in the head with the debarking set and a total time consumption for processing a trunk using the conventional head was only $5.7 \mathrm{~s}$ in the improvement felling and $3.7 \mathrm{~s}$ in the main felling.

The authors are aware of differences in the average stem volume of cut trunks between the compared plots at both locations. Time consumption for processing a trunk 
increases with its increasing stem volume $[26,27]$ and because its length is also increasing, the time consumption for delimbing grows [30]. Time consumption is also higher due to a higher number of cross-cuts at processing longer stems and a higher number of assortments [31-33]. Produced assortments have to be stacked, which again increases the time consumption [32]. Nevertheless, the harvester efficiency increases with the increasing stem volume [34-38]. If we compare the differences in time required for the processing of trees of different stem volumes on the experimental plots in the main felling and in the improvement felling (on average $9.7 \%$ ), it can be stated that an error caused by the different stem volume within one type of felling is minimal and shows a possible slight increase in time needed for the work of the harvester head with the debarking set.

Apart from the above factors, the work efficiency of a harvester can also be affected by the different experience of the operators and the selected work procedure $[38,39]$. In this sense, Purfüst [40] points to the level of an operators' skill in the machine control and their capability of learning by which their work is accelerated. To be able to eliminate the possibility of the data gained being affected by the operator as much as possible, the harvester deployed in one type of logging was at all times operated by one person.

Theoretical differences in the daily output of a harvester in the main felling and improvement felling with the classic harvester head and harvester head equipped with the debarking set can be illustrated on a model example. If an output of the harvester with the conventional head is $200 \mathrm{~m}^{3}$ u.b., it will be reduced to ca. $82 \mathrm{~m}^{3}$ u.b. with the use of a harvester head with the debarking set. Similarly, in the improvement felling, a standard daily output can be reduced from $50 \mathrm{~m}^{3}$ u.b. to ca. $21 \mathrm{~m}^{3}$ u.b. The debarking head is therefore appropriate to use when a smaller number of trees are attacked by the bark beetles or if fast transport of felled trees from forest stands is not ensured. It is also possible to use a debarking head in places for the protection of water resources or also before the start of a bark beetle outbreak. However, it is necessary to take into account the additional costs of about $6.0 €$ per $\mathrm{m}^{3}$, which can be problematic due to the amount of infested wood in the forest stand and its damage by the debarking head, as found in this article.

According to our results, the quality of spruce stem debarking in the main felling was on average $84.5 \%$, which almost precisely corresponds with the research made by Heppelmman et al. [21], who recorded values ranging from 83 to $84 \%$. In the improvement felling, the area under bark was $64.5 \%$ in the average spruce stem. Damage to the stem surface was recorded in $50 \%$ of produced logs. Labelle et al. [19] identified the damage as damage II, which was localized on $18-23 \%$ of stem area with a depth up to $18.9 \mathrm{~mm}$. In our measurements, we recorded a damage depth in the order of centimeters. The reason for such extensive damage was the inappropriate adjustment of the pressure of delimbing knives on the harvester head, which made it impossible for a smooth start of feed rollers. In practice, the fact showed a need to slightly open the delimbing knives in order to facilitate the stem movement in the head. Our findings are in line with the statement of Heppelmman et al. [22] regarding the possibility of eliminating the risk of damage to the stem by reducing the pressure of delimbing knives.

Based on the data recorded in our research, the dependence of debarking quality on the moisture content was not demonstrated, as noted in previous research $[18,22]$. However, as our measurements were taken at the end of the growing season, they do not represent a general trend. Therefore, the independence of debarking quality on the stem moisture content can be stated only within short-term fluctuations.

\section{Conclusions}

In summary, it can be stated that harvester heads with the debarking set cannot compete in efficiency with the conventional harvester heads (their efficiency was $41.2 \%$ lower in the main felling and $41.8 \%$ lower in the improvement felling). Delimbing/debarking operations contributed the most to the reduction in the harvester's efficiency $(50.8 \%$ in the main felling and $49.4 \%$ in thinning). 
The highest quality of debarking was recorded in the middle part of the trunk with a diameter of 13 to $23 \mathrm{~cm}$ (main felling 91.0\%, thinning 76.6\%). The lowest quality of debarking was recorded in the top parts of the stem with a diameter of up to $13 \mathrm{~cm}$ (main felling $74.2 \%$, thinning $52.2 \%$ ). The measurement took place at the end of the growing season and during this period, no dependence of the debarking quality on the stem moisture was found. The relationship between debarking quality and the log diameter was demonstrated.

Nevertheless, further development and an increasing need for the application of harvest heads with debarking modifications are expected.

In today's situation of obvious climate change and more and more frequent damage to forest stands due to weather conditions (drought, windbreaks, etc.), the vitality of forest ecosystems is decreasing and the danger of bark beetle calamities is increasing.

Due to the need for rapid work in damaged forest stands in order to maintain forest ecosystems as well as obtain a certain economic benefit of logs from sanitary felling, it provide advantages to harvesting heads with debarking modifications despite the expected lower efficiency and efficiency compared to conventional harvester heads. This reduced efficiency will result in additional costs of around $6 €$ per $\mathrm{m}^{3}$.

Author Contributions: Conceptualization, V.M. and T.Z.; Methodology, V.M.; Software, V.M.; Validation, V.M. and T.Z.; Formal analysis, V.M. and T.Z.; Investigation, V.M. and T.Z.; Resources, V.M. and J.K.; Data curation, V.M.; Writing—original draft preparation, V.M.; Writing-review and editing, V.M., T.Z., and M.Š.; Visualization, V.M. and J.K.; Supervision, T.Z. and M.Š.; Project administration, T.Z.; Funding acquisition, T.Z. All authors have read and agreed to the published version of the manuscript.

Funding: This research was funded by the Technology Agency of the Czech Republic, grant number TH03010007.

Institutional Review Board Statement: Not applicable.

Informed Consent Statement: Not applicable.

Data Availability Statement: The data presented in this study are available in the article. Additional data are available on request from the corresponding author.

Acknowledgments: The publication makes use of findings acquired during the solution of research project no. TH03010007 Harvester prototype with multifunctional travel and hybrid drive.

Conflicts of Interest: The authors declare no conflict of interest.

\section{References}

1. Forest Economic Advisors. Central European Beetle \& Windstorm Timber Disaster Report. Available online: https://getfea.com/ publication/central-european-beetle-windstorm-timber-disaster (accessed on 3 September 2021).

2. International Forest Industries. Spruce Bark Beetle and Its Impact on Wood Markets. Available online: https:// internationalforestindustries.com/2020/06/09/spruce-bark-beetle-impact-wood-markets / (accessed on 3 September 2021).

3. Ministry of Agriculture of the Czech Republic. Information on Forests and Forestry in the Czech Republic by 2019; Ministry of Agriculture of the Czech Republic: Praha, Czech Republic, 2020; ISBN 978-80-7434-571-5.

4. Ministry of Agriculture of the Czech Republic. Information on Forests and Forestry in the Czech Republic by 2016; Ministry of Agriculture of the Czech Republic: Praha, Czech Republic, 2017.

5. Grégoire, R.; Raffa, K.; Lindgren, S. Economics and Politics of Bark Beetles. In Bark Beetles: Biology and Ecology of Native and Invasive Species, 1st ed.; Vega, E., Hofstetter, W., Eds.; Academic Press: London, UK, 2015; pp. 585-613. ISBN 978-012-417156-5.

6. Hlásný, T.; Krokene, P.; Liebhold, A.; Müller, J.; Qin, H.; Raffa, K.; Schelhaas, M.J.; Seidl, R.; Svoboda, M.; Viiri, H. Living with Bark Beetles: Impacts, Outlook and Management Options, 1st ed.; Europian Forest Institute: Joensuu, Finland, 2019; ISBN 978-952-5980-75-2.

7. Kundzewicz, W.; Parry, L. Europe. In Climate Change 2001: Impacts, Adaptation and Vulnerability, 1st ed.; McCarthy, J., Canziani, O., Leary, N., Dokken, D., White, K., Eds.; Cabridge University Press: Cambridge, UK, 2001; pp. 643-692. ISBN 0-521-80768-9.

8. Kovats, R.S.; Valentini, R. Europe. In Climate Change 2014_Impacts, Adaptation and Vulnerability: Regional Aspects, 1st ed.; Cabridge University Press: New York, NY, USA, 2014; pp. 643-692. ISBN 978-7-107-05816-3.

9. Netherer, S.; Schopf, A. Potential effects of climate change on insect herbivores in European forests-General aspects and the pine processionary moth as specific example. For. Ecol. Manag. 2010, 259, 831-838. [CrossRef] 
10. Jönsson, A.M.; Harding, S.; Krokene, P.; Lange, H.; Lindelöw, Å.; Økland, B.; Ravn, H.P.; Schroeder, L.M. Modelling the potential impact of global warming on Ips typographus voltinism and reproductive diapause. Clim. Chang. 2011, 109, 695-718. [CrossRef]

11. Seidl, R.; Schelhaas, M.; Rammer, W.; Verkerk, P.J. Increasing forest disturbances in Europe and their impact on carbon storage. Nat. Clim. Chang. 2014, 4, 806-810. [CrossRef] [PubMed]

12. Hlásný, T.; König, L.; Krokene, P.; Linder, M.; Montagné-Huck, C.; Müller, J.; Qin, H.; Raffa, F.K.; Schelhaas, M.; Svoboda, M.; et al. Bark Beetle Outbreaks in Europe: State of Knowledge and Ways Forward for Management. Curr. For. Rep. 2021, 7, 138-165. [CrossRef]

13. Zahradník, P.; Zahradníková, M. Metody Asanace Kưrovcového Dříví a Ochrana Skládek, 1st ed.; Lesnická Práce: Kostelec nad Černými lesy, Czech Republic, 2018.

14. Kindelmann, P.; Matějka, K.; Doležal, P. Lesy Šumavy, Lýkožrout a Ochrana Přrirody, 1st ed.; Karolinum: Prague, Czech Republic, 2012; ISBN 978-80-246-2155-5.

15. Dinu, M.M.; Lupäştean, D.; Cardaş, G.; Andrei, A. New Beauveria bassiana (Bals.) Vuill. Isolate from Ips duplicatus (Sahlberg). Rom. J. Plant Prot. 2012, 5, 12-15.

16. Mendel University in Brno. CZ 33942 U1. Available online: https://isdv.upv.cz/doc/FullFiles/UtilityModels/FullDocuments/ FDUM0033/uv033942.pdf (accessed on 17 May 2021).

17. Gzülci, N.; Akay, A.E.; Erdaş, O. Productivity assessment of alternative timber debarking methods. Sumar. List 2017, 141, 469-476. [CrossRef]

18. Heppelmann, J.B.; Labelle, E.R.; Steeling, U.; Wittkopf, S. Evaluating the debarking efficiency of modified harvesting heads on European tree species. In Proceedings of the 49th Symposium on Forest Mechanization, Warsaw, Poland, 4-7 September 2016; pp. 49-52.

19. Labelle, E.R.; Breinig, L.; Spinelli, R. Extent and severity of damages caused to spruce roundwood by harvesting heads in standard versus debarking configurations. Eur. J. For. Res. 2019, 138, 151-163. [CrossRef]

20. Moore, G.; McMahon, T. Bark/wood bond strength and its association with material and environmental variables. Wood Fiber Sci. 1986, 18, 526-536.

21. Murphy, G.; Acuna, M. Effect of harvesting season, systém and equipment on in-forest Pinus radiata bark removal in Australia and New Zealand. Int. J. For. Eng. 2017, 28, 10-17. [CrossRef]

22. Heppelmann, J.B.; Labelle, E.R.; Wittkopf, S.; Seeling, U. In-stand debarking with the use of modified harvesting heads: A potential solution for key challenges in European forestry. Eur. J. For. Res. 2019, 138, 1067-1081. [CrossRef]

23. Bennemann, C.; Heppelmann, J.; Wittkopf, S.; Hauck, A.; Grünberger, J.; Heinrich, B.; Seeling, U. Debarking Heads. LWFaktuell 2020, 125, 44-46.

24. Holzleitner, F.; Holzfeind, T.; Messner, S.; Kanzian, C. Integrated in-stand debarking with harvester in cut-to-length operation. In Proceedings of the SNS CAR NB NORD Conference, Helsinore, Denmark, 22-24 September 2020; pp. 117-120.

25. Heppelmann, J.B.; Labelle, E.R.; Seifert, T.; Seifert, S.; Wittkopf, S. Development and Validation of a Photo-Based Measurement System to Calculate the Debarking Percentages of Processed Logs. Remote Sens. 2019, 11, 1133. [CrossRef]

26. Eliasson, L. Simulation of Thinning with a Single-Grip Harvester. For. Sci. 1999, 45, 26-34. [CrossRef]

27. Brewer, J.; Talbot, B.; Belbo, H.; Ackerman, P.; Ackerman, S. A comparison of two methods of data collection for modelling productivity of harvesters: Manual time study and follow-up study using on-board-computer stem records. Ann. For. Res. 2018, 61, 109-124. [CrossRef]

28. European Commission. Regions 2020: The Climate Challenge for European Regions. Available online: http:/ / ec.europa.eu/ regional_policy/sources/docoffic/working/regions2020/pdf/regions2020_climat.pdf (accessed on 3 September 2021).

29. Zscheischler, J.; Fischer, E.M. The record-breaking compound hot and dry 2018 growing season in Germany. Weather Clim. Extremes 2020, 29, 100270. [CrossRef]

30. Nakagawa, M.; Hamatsu, J.; Saitou, T.; Ishida, H. Effect of Tree Size on Productivity and Time Required for Work Elements in Selective Thinning by a Harvester. Int. J. For. Eng. 2007, 18, 24-28. [CrossRef]

31. Tufts, R.A.; Brinker, R.W. Productivity of a Scandinavian cut-to-length system while second thinning pine plantations. For. Prod. J. 1993, 43, 24-32.

32. Suadicani, K.; Fjeld, D. Single-tree and group selection in montane Norway spruce stands: Factors influencing operational efficiency. Scand. J. For. Res. 2001, 16, 79-87. [CrossRef]

33. Horváth, A.L.; Mátyás, K.S.; Czupy, I. The effect of independent variables of time equations at the logging with harvesters. In Proceedings of the 49th Symposium on Forest Mechanization, Warsaw, Poland, 4-7 September 2016; pp. 53-59.

34. Puttock, D.; Spinelli, R.; Hartsough, B.R. Operational trials of cut-to-length harvesting of poplar in a mixed wood stand. Int. J. For. Eng. 2005, 16, 39-49. [CrossRef]

35. Ramantswana, M.; McEwan, A.; Steenkamp, J. A comparison between excavator-based harvester productivity in coppiced and planted Eucalyptus grandis compartments in KwaZulu-Natal, South Africa. South. For. 2013, 75, 239-246. [CrossRef]

36. Strandgard, M.; Mitchell, R.; Acuna, M. General productivity model for single grip harvesters in Australian eukalyptus plantations. Aust. For. 2016, 79, 108-113. [CrossRef]

37. Norihiro, J.; Ackerman, P.; Spong, B.D.; Längin, D. Productivity Model for Cut-to-Length Harvester Operation in South African Eucalyptus Pulpwood Plantations. Croat. J. For. Eng. 2018, 39, 1-13. 
38. Ovaskainen, H.; Uusitalo, J.; Väätäinen, K. Characteristics and Significance of a Harvester Operators' Working Technique in Thinnings. Int. J. For. Eng. 2004, 15, 67-77. [CrossRef]

39. Nurminen, T.; Korpunen, H.; Uusitalo, J. Time consumption analysis of the mechanized cut-to-length harvesting system. Silva Fenn. 2006, 40, 335-363. [CrossRef]

40. Purfürst, F.T. Learning Curves of Harvester Operators. Croat. J. For. Eng. 2010, 31, 89-97. 